\title{
Role of Polymerase Chain Reaction in Forensic Entomology
}

\author{
Tock Hing Chua ${ }^{1}$ and Y. V. Chong ${ }^{2}$ \\ ${ }^{1}$ Department of Parasitology and Medical Diagnostics, Universiti Malaysia Sabah, \\ Jalan UMS, Kota Kinabalu, Sabah, \\ ${ }^{2}$ Monash University, Jalan Lagoon Selatan, Bandar Sunway, Selangor Darul Ehsan \\ Malaysia
}

\section{Introduction}

The history of forensic entomology dates back to the $13^{\text {th }}$ century when Song Ci (or Sung Tz'u) (1186-1249), an outstanding forensic scientist in the Southern Song Dynasty, documented the first forensic entomology case in his book "Collected Cases of Injustice Rectified" (Xi Yuan Ji Lu which means "Washing Away of the Wrongs"). In his investigation, Song Ci identified the murderer through forensic flies which flew to the sickle used in committing the crime. This sickle had bits of soft tissue, blood, bone and hair attached to it and thus attracted the flies. The owner of the sickle then admitted to his crime (translated by McKnight [1]).

Insects (mainly flies and beetles) are the main resources in forensic entomology. They could be found in every part of the world making them a useful forensic indicator by providing useful clues and evidence in death and criminal cases in forensic investigations.

With the advancement of biotechnology, forensic entomology has become a technically well developed field. Molecular biology tools are incorporated into this field where DNA based techniques are used to help solving complicated criminal or death cases. Often, police seek scientist's help to perform these genetic techniques mainly involving Polymerase Chain Reaction (PCR) analysis.

Today, the use of PCR-based methods in forensic entomology to help solve criminal and death investigations is continually increasing. In fact, it is a standard tool in most forensic laboratories, and police officers are trained in molecular technology.

In this chapter, we will look into the various PCR-based methods that have been developed elsewhere and adopted in forensic entomology, focusing on medicocriminal entomology. We will also look into how each method contributes to the field, as well as discussing its strengths and weaknesses.

\section{Estimation of Post Mortem Interval (PMI)}

Forensic entomologists estimate the post-mortem interval (PMI) or the minimum time of death by analyzing the correlation between the developmental stages of the collected insect 
specimens with the approximate weather data at the time when the crime or death occurs. Within minutes of the death of a person, forensic insects are able to locate the body through the sense of smell. The female fly deposits eggs (in the case of Calliphorid flies) or larvae (for Sarcophagid flies) on open wounds or natural openings of the corpse. These larvae hatch from eggs or born alive would then feed on the corpse. The larva undergoes three developmental stages and moults into a pupa. Metamorphosis occurs within the pupa, and an adult fly emerges in about a week.

Flies are usually the insects that arrive first at the decomposing corpse, starting with Calliphorids such as Chrysomya megacephala (Fabricius) and Chrysomya rufifacies (Macquart), and Sarcophagids. Following the flies, a succession of other arthropods and species of other phyla such as beetles, ants, moth, butterflies, earthworms and snails would arrive and join in decomposing the corpse. These include the beetles (Family Dermestidae and Silphidae), wasps (Family Vespidae), ants (Order Hymenoptera) and mites (gamasid and oribatid mites).

The arrival time of each individual species differ; some species such as blowfly and flesh fly arrive within five minutes prior to death while other species such as soldier fly and beetles arrive when the corpse is at the advanced decay stage [2]. The developmental rate of each species and each immature stage differs, and variation exists even among closely related species. Thus, correct species identification of the collected specimens and realistic values of the development rate of immature stages are very crucial for accurate PMI estimation.

\section{Species identification using molecular methods}

Insect species identification has been traditionally carried out using morphological characteristics. However, morphological characteristic keys for the immature stages of many forensically important species are either not constructed yet or not easily available or appear confusing to the non experts. To overcome this problem, forensic workers have started using Polymerase Chain Reaction (PCR) in insect species identification for forensic entomology since 1994.

The DNA of the insect specimen collected from the corpse or criminal scene is extracted usually using a commercial extraction kit and the extracted DNA is amplified using a specific primer designed for a certain gene. Then, the desired amplified fragment is purified for sequencing, and the sequence obtained is analysed further using Bioinformatics tools.

For species identification in forensic entomology, further investigation subsequent to the simple PCR analysis is commonly carried out by random fragment length polymorphism (RFLP), randomly amplified polymorphic DNA (RAPD), inter simple sequence repeat (ISSR) and sequence-characterized amplified region (SCAR) marker methods and real time PCR analysis.

\subsection{Simple PCR}

The DNA-based method as an alternative to using morphological keys for species identification was first proposed by Sperling et al. [3]. In his research, mitochondrial DNA 
(mtDNA), mitochondrial cytochrome oxidase I (COI), cytochrome oxidase II (COII) and tRNA leucine genes of blowflies (Phormia regina (Meigen), Phaenicia sericata (Meigen) and Lucilia illustris (Meigen)) were amplified using PCR and followed by direct sequencing. He found that there were nucleotide differences in the DNA sequences between these three species which could be used to differentiate their immature larval stages.

Subsequent to this research, mtDNA has been widely used for DNA analysis in forensic entomology, using COI and COII gene sequences analysis for distinguishing forensically important blow flies and flesh flies [4-14]. In purpose, such molecular work is similar to other non-entomological forensic methods in that it provides supplementary evidence in the form of PMI estimate to support the charge of a suspect to the crime.

In China, a $278 \mathrm{bp}$ region of COI was used for the identification of nine forensic flies, namely Ophyra capensis (Wiedemann), Chrysomya megacephala, Phaenicia sericata, Lucilia curpina, and Boettcherisca peregrina (Robineau-desvoidy) [15]. They found the species could be easily separated by molecular means except for Phaenicia sericata and Lucilia curpina because of low sequence divergence between these two species.

In 2010, Mazzanti et al. [16] demonstrated that PCR could successfully amplify the mtDNA from empty puparial case and also fragments of the case. They could also correctly determine the eight Dipteran species (Calliphora vicina (Robineau-Desvoidy), Sarcophagidae crassipalpis (Macquart), Phormia regina, Phaenicia sericata, Sarcophaga argyrostoma (RobineauDesvoidy), Calliphora vomitoria (Linnaeus), Chrysomya megacephala, Synthesiomyia nudiseta (Van Der Wulp)) through the amplified DNA from pupal case. This finding is particularly important as empty pupa cases left after adult emergence or fragments of it are commonly found on the corpse or in the area surrounding the corpse. The mtDNA has also been used for identification of beetle species found on corpses. In addition, COI and COII sequences have been used to study the phylogenetic relationships of carrion beetles species (Silphidae) (Nicrophorus investigator Zetterstedt, Oiceoptoma novaboracense (Förster), Necrophilia americana (Linnaeus) [17].

However molecular identification of species may not be accurate if it uses only the mtDNA gene [18]. More recent works also make use of internal transcribed spacer (ITS) which is a piece of non-functional RNA situated between structural ribosomal RNAs (rRNA) on a common precursor transcript. This transcript contains the $5^{\prime}$ external transcribed sequence (5' ETS), 18S rRNA, ITS1, 5.8S rRNA, ITS2, 28S rRNA and finally the 3'ETS. The ITS region is widely used in taxonomy and molecular phylogeny because it is easy to amplify even from small quantities of DNA (due to the high copy number of rRNA genes) and has a high degree of variation even between closely related species.

For example, Song et al. [19] analyzed the nuclear ribosomal DNA especially internal transcribed spacer-II (ITS2) for species identification of some common necrophagous flies in southern China by phenetic approach. ITS2 gene was amplified from each individual specimen and sequences obtained were analyzed using ClustalX to construct a neighbour joining (NJ) tree. The results showed that species could be differentiated, and the identification was not affected by intra and interspecific variations. However, because of the high sequence homology between some congeneric species, more sequencing of specimens is required before such method can be used for forensic investigations. 
A different section of the COI, a 250 base pair region of the gene for $16 \mathrm{~S}$ rDNA has also being sequenced and tested [20]. They examined eight forensically important species from ten sites distributed at nine provinces in China. These were Chrysomya megacephala, Chrysomya rufifacies, Calliphora vicina, Lucilia caesar (Linnaeus), Lucilia porphyrina, Phaenicia sericata (Meigen), Lucilia bazini (Seguy), Lucilia illustris (Meigen). Their analysis of $16 \mathrm{~S}$ rDNA sequences indicated abundant phylogenetically informative nucleotide substitutions which could identify most of the species tested except for specimens of Lucilia caesar and Lucilia porphyrina.

In a more recent study [21], species diagnosis of blowflies (Chrysomya megacephala, Chrysomya pinguis (Walker), Phaenicia sericata, Lucillia porphyrina (Walker), Lucillia illustris (Meigen), Hemipyrellia ligurriens (Wiedemann), Aldrichina grahami (Aldrich) and Musca domestica L.) from China and Pakistan was explored using phylogenetic analysis with five gene segments. They found that more accurate results were achieved through multi gene trees compared to single gene especially in resolving evolutionary relationship between species.

Although the mitochondrial cytochrome c oxidase gene is a favourite amongst forensic entomologists resulting in vast amount of DNA data being generated, there is little agreement as to which portion of the gene to be sequenced in forensic work, as different workers used different primers and obtained different sequence lengths from different regions. This can be seen from the above works quoted in this paper, and thus sequence analysis across species may be difficult. If agreement can be reached between various workers, a COI barcode identification system can be developed for use internationally. For example, such a system, using a 658-bp fragment of the COI, was found to be suitable for the identification of Chrysomya species from Australia [22]. This COI barcode region can facilitate the rapid generation of a barcode database and subsequent identification of specimens.

\subsection{Restriction fragment length polymorphism (RFLP)}

PCR-RFLP is the next method developed for species identification and separation. It is robust, easy and inexpensive. It detects the difference in homologous DNA sequences in the form of fragments of different lengths after digestion of the DNA samples in question with specific restriction endonucleases. Thus this technique is a combination of PCR amplification and RFLP analysis, in which the desired amplified product is digested with one or more restriction enzymes. Banding patterns that are specific for each species produced from the restriction digestion can be used for identification.

Schroeder et al. [23], for example, analyzed three forensically important species in Germany using the PCR-RFLP technique. They amplified specific fragments of the COI and COII region of the mitochondrial DNA (mtDNA) which were then digested with different restriction enzymes (either DraI or HinfI). The results revealed that a short sequence of 1.3 $\mathrm{kb}$ of COI and COII regions could differentiate the three species (Phaenicia sericata, Calliphora vicina and Calliphora vomitoria). Similarly the restriction enzyme SfcI was utilised on cytochrome oxidase I gene region to distinguish between Calliphora vicina and Calliphora vomitoria, two of the main UK blowfly species [12]. 
The utility of COI gene for identification of important forensic blow fly species found in Taiwan (Chrysomya megacephala, Chrysomya rufifacies, Chrysomya pinguis, Hemipyrellia ligurriens (Wiedemann), Lucillia bazini Seguy, Lucilia cuprina, Lucillia hainanesis Fan and Lucilia prophyrina) using different stages and different parts of the fly individual was also tested [11], and high support for congeneric grouping of species were obtained.

The PCR-RFLP techniques have also been employed elsewhere, using the internal transcribed spacer (ITS) in addition to COI. For example, three major blow fly species in Taiwan (Chrysomya megacephala, Chrysomya pinguis and Chrysomya rufifacies) could be successfully differentiated using COI and internal transcribed spacer I (ITS1) [24]. In Australia, the potential use of internal transcribed spacer II (ITS2) was investigated using PCR-RFLP analysis on all known Chrysomya species known from Australia [22]. All the species produced distinct restriction profiles except for the closely related species pairs, viz. between Chrysomya latifrons Malloch and Chrysomya semimetallica Malloch, and between Chrysomya incisuralis Macquart and Chrysomya rufifacies.

Recently, we carried out research on the PCR-RFLP assay for twelve Malaysian forensically important fly species. Our results (unpublished) indicate that the twelve species (Chrysomya megacephala, Chrysomya rufifacies, Chrysomya pinguis, Chrysomya bezziana (Villeneuve), Chrysomya villenuevi, Chrysomya nigripes (Aubertin), Lucillia cuprina (Wiedemann), Ophyra spinigera (Stein), Sarcophaga ruficornis (Liopygia), Sarcophaga dux (Thomson), Sarcophaga peregrina (Robineau-Desvoidy) and Hermetia illucens (Linnaeus)) in the study could be differentiated through COI gene digestion with three restriction enzymes (HpaII, SspI and $\mathrm{HpyCH} 4 \mathrm{~V})$. We found that this method could be applied to immature stages and also incomplete specimens collected from the criminal scene.

\subsection{Randomly amplified polymorphic DNA (RAPD)}

RAPD is another commonly used method for species identification. This method uses nonspecific primers for PCR amplification by which different regions of the DNA sample are amplified. The first RAPD typing of forensic insects was reported 1998 [4]. Eleven RAPD primers were tested to differentiate closely related species of flies and beetles found on corpse such as 'green bottle' blow flies, 'blue bottle' blow flies (Diptera: Calliphoridae) and beetles (Coleopyera: Silphidae). He found one particular primer (REP1R XIIIACGTCGICATCAGGC) was sufficient in resolving a practical forensic situation, but suggested for forensic purposes a set of at least six primers should be used to establish similarity coefficients. Nevertheless, he cautioned that in medico-legal matters, RAPD results may only be reported for so-called exclusions (where two specimens are definitely proven to be different) since an inclusion (where two specimens are shown to be similar or directly related) might induce the question of the likelihood of finding the same RAPD pattern by chance in any other animal.

\subsection{Inter simple sequence repeat (ISSR) and sequence-characterized amplified region (SCAR) markers methods}

ISSRs are DNA fragments of about 100-3000 bp located between adjacent, oppositely oriented microsatellite regions, and the variation in the regions between these 
microsatellites is used in ISSR PCR genotyping. The primers used are microsatellite core sequences with a few selective nucleotides as anchors into the non-repeat adjacent regions $(16-18 \mathrm{bp})$. The advantage of ISSRs is that no sequence data for primer construction are needed.

The inter simple sequence repeat (ISSR) method was used to analyze the DNA polymorphism among the five forensic fly species in China, namely, Phaenicia sericata, Aldrichina grahami, Chrysomya megacephala, Parasarcophaga crassipalpis and Musca domestica using [25]. They found that nine ISSR primers could amplify 95 polymorphic bands which can be used to identify these species. They further converted these species-specific ISSR fragments into the sequence-characterized amplified region (SCAR) markers that can be used for the molecular diagnosis of these species.

Determination of specimens using ISSR is based on the similarity and difference in the electrophoresis result when compared with other individuals. For a high reliability of identification, such method requires a reference sample from the same species in a large database containing all species likely to be attracted to corpses in the same geographic region. On the other hand, SCAR is a genomic fragment localized in a single genetically defined locus that can be amplified by PCR using a pair of specific primers. SCARs are less sensitive to reaction conditions when compared to ISSR markers, thus allowing for a higher reliability and reproducibility among different laboratories which may use different brands of reagents and equipment. Therefore, SCARs are more appropriate diagnostic tool for practical applications.

\subsection{Real time PCR assay}

Further development in molecular identification of species was achieved in 2010 [26]. The investigators designed a species-specific real-time polymerase chain reaction (PCR) assay to target the ribosomal DNA internal transcribed spacer 1 (rDNA ITS1) of Chrysomya bezziana. It was very specific and can exclude other morphologically similar and related Chrysomya and Cochliomyia species. With this they were able to detect one Chrysomya bezziana in a sample of 1000 non-target species. Similar specific system can be developed to confirm the identity of other Chrysomya spp.

\section{Determination of insect developmental rate}

Immature stages of flies particularly the larvae and pupae, are often recovered from the death scene. Obtaining a better estimate of the time needed for the immature insect to develop to a certain stage will help to give a more accurate PMI. The larva and pupa stages occupy more than half of the immature development time. The developmental rate of larvae is determined by specific morphological changes and measurement of the specimen length [27-29]. For the egg and pupa which do not change size, physical measurement is not very useful. However, the changes of the pupal case and measurement of hormone level have been used for determining the pupa developmental rate of Protophormia terraenovae (Robineau-Desvoidy) [30].

Recently, molecular techniques involving PCR analysis have been developed for the developmental time of immature stages of the blowfly, Phaenicia sericata. Tarone et al. [31] 
profiled the expression of three genes (bcd, sll, cs) throughout the maturation of blow fly eggs, and found the expression data could predict more precisely the blow fly age (within 2 $\mathrm{h}$ of true age). Later, they continued to work on the larvae and pupae [32]. Samples were collected from the carcass at different time intervals for gene expression evaluation. The RNA of the sample was extracted and the complementary DNA (cDNA) was synthesized from the RNA using specific gene primers. The desired developmentally regulated gene expression levels were assessed by quantitative PCR, and these levels were incorporated into traditional stage and size data. They tested on 86 immature Phaenicia sericata, and obtained a better precision in ageing blow flies, especially for postfeeding third instars and pupae.

Real time PCR and differentially expressed genes have also been used in the determination of pupal age in Calliphora vicina [33]. This research indicated that expression of Arylphorin and Gene $G$ genes is possible to determine the age of the immature stages. Arylphorin gene is highly expressed at the early stage of pupae development (at 4500 accumulated degree 14 hours or ADH) whereas Gene G is highly expressed at the end of pupae stage (at 8640ADH). On the other hand, the changes in gene expression using differential display PCR has also been investigated [34]. The data showed that different genes are expressed at different levels during pupal development of Phaenicia sericata. However, they admitted that their method was not able to determine a pupa's age as yet.

Further research was carried out to improve estimation of the age of blow fly (Phaenicia sericata) with the aim of achieving a more accurate and precise PMI approximate, through gene expression where 20 genes were analyzed using RT-PCR [32]. Nine of these genes viz. resistance to organophosphate 1 (rop-1), acetylcholine esterase (ace), chitin synthase (cs), ecdysone receptor (ecr), heat shock protein 60 and 90 (hsp60, hsp90), slalom (sll), ultraspiracle (usp), and white (w) evaluated in this study were found to be useful in increasing the accuracy of PMI estimation for post feeding third instars and pupae.

\section{Genetic variation of forensic species population for detecting postmortem relocation}

Research on genetic variation of common forensically important species between populations is important for forensic studies. The genetic data of these species is likely to be different among different populations. If specimens from only one location were used in the research, the data collected might only be accurate for that particular location and it could not be applied to death investigations which occur at other locations. It might also be possible to detect post-mortem relocation of a corpse through the study of genetic variation among populations within a species. For study in a particular geographical area, PCR analysis is usually coupled with RAPD, amplified fragment length polymorphism (AFLP) and inter simple sequence repeat (ISSR). In these methods, non-specific primers are used for PCR amplification. RAPD fingerprinting could be a valuable tool for separating various populations [35].

The intraspecific genetic variation of Phaenicia sericata between two populations in southern England has been investigated using RAPD analysis [36]. The genetic homogeneity of Phaenicia sericata was determined, basing on the RAPD data which was analysed using a 
similarity coefficient method and a randomization test. They found that banding profiles (which were defined with ten random primers) from RAPD could differentiate among closely related individuals of the species. Such investigation can be used to elucidate relationships between even closely related populations of Phaenicia sericata and differentiate between populations, if more than a population is found on the corpse, thus helping to make a conclusion if a body had been relocated prior to its discovery.

Similarly, AFLP analysis has also been used for genetic population study of Phormia regina from sites spanning the contiguous United States [37]. They found there was only a very weak correlation between individual genetic and geographic distances. More interestingly, they found that adult Phormia regina that arrived together to the baits were closely related individuals compared to a random sample. They later applied the same method for investigating the population genetic structure of Phaenicia sericata from North America based on AFLP genotypes with 249 loci [38]. Although the study could not find any regional genetic variation, they nevertheless detected high local relatedness among the females in the samples. This led them to suggest that a pattern of local relatedness might support a genetic test for inferring the post-mortem relocation of a corpse.

We have conducted using similar methods a preliminary study of the population genetic variation among Chrysomya megacephala individuals in Malaysia. We tested the usefulness of COI gene for differentiating Malaysian Chrysomya megacephala individuals from four locations. Our results showed that the individuals could be put into two geographical groups based on a single nucleotide polymorphism (SNP) observed (unpublished results). It would appear possible then to infer if a corpse has been relocated from one location to another by comparing the SNP of larvae or pupae left behind at one place and those on the corpse which has been moved postmortem.

\section{Recovery of human DNA from insects}

Many studies found that human DNA can be recovered from insects found at the scene. The recovery of DNA provides useful information for forensic cases. For example, the identity of the suspect or the deceased could be identified from a fed mosquito, fly larvae or bed bugs [39-43]. The detection of insect gut content by PCR amplification is useful for forensic entomology. DNA is extracted from the collected insect, often from the insect gut contents. Then PCR amplification usually is conducted using either short tandem repeat (STR), human mtDNA hypervariable region (HVR) or insect mtDNA for profiling. STR and HVR typing are commonly used for human profiling.

Coulson et al. [44] demonstrated the possibility of human DNA extraction, amplification and fingerprinting from Anopheles gambiae mosquitoes stored at different storing conditions. The results showed that it is possible to use PCR for the amplification of human DNA extracted from mosquitoes. A very interesting casework has been demonstrated in 2006 [41], where only a fresh mosquito blood stain from a smashed mosquito was found in a room of the death scene. DNA was successfully extracted from the blood stain, and PCR amplification and STRs profiling at 15 human genetic loci was then performed on the extracted DNA, using AmpFLSTR Identifiler. This produced a complete genetic profile which aided the identification of the suspect. 
A number of researches were conducted on the DNA extraction from the digestive tract of necrophagous larvae or the 'last meal' of these maggots. This is a useful study as the DNA profile of the host could be obtained from the extracted DNA and to determine whether the maggots used in the investigation are associated with the crime or death [40, 45]. Kondakci et al. [46] found that a complete human profile could be obtained using STR and SNP profiling of Phaenicia sericata third instar larvae. The STR and SNP profiles matched the identity of the host which showed that this analysis could be used to relate the maggots studied to the corpse in the investigation.

\section{Conclusion}

With the advent of molecular techniques, forensic entomology has certainly come a long way since the days of Song $\mathrm{Ci}$. Molecular technology has changed the manner by which forensic entomological investigations are being carried out, making it a sophisticated a science. This has resulted in quicker, more accurate determination of the species, as well as the age of specimens recovered from the corpse, and consequently a more accurate of PMI.

From the initial use simple PCR in forensic entomology, it has progressed to RFLP, then RAPD, ISSR, SCAR and finally to RT- PCR Assay.

Initially the molecular techniques were used mainly for species identification [3, 23, 24]. However, later works extended to ageing the pupa [33], which is very useful as the size does not change during metamorphosis, and physical ageing is not possible. The accuracy of PMI estimates increases if ageing of the immature stages becomes more precise.

It would appear that future research is in the direction of RT-PCR assay, as this is a faster and more accurate method. Similarly studies on the intraspecific genetic variation on forensic insect populations will result in more accurate methods of population identification, and aid in deciding if a victim's body has been relocated by the criminals for burial to avoid suspicion, or to mislead criminal investigation.

Another area which has great potential use is identification of suspect from the gut content of a fed mosquito [44] or body louse [47] at the crime scene. In the case where the body has been moved, the carrion fly larvae or pupae may help identify the deceased indicating the relocation of the corpse. Although the blood meal may be partially digestion and makes DNA extraction difficult, future research will likely to yield better technology for genotyping profile with degraded or low-copy DNA template.

Although molecular methods have advanced forensic entomology, the validity and reliability of the methods, and have also questioned the statistical basis of the sampling size have been questioned [18], and suggestions to improve have been offered. Among many things, it was suggested (a) the DNA extraction procedure should include a negative control, and the genotyping procedures should include both positive and negative controls, (b) a portion of the original tissue should be saved so that it is available for independent testing, (c) there must be an extensive record of reproducibility under specified working conditions, both when performed by the same analyst and by different analysts, (e) the analyst should have considerable experience with the particular genotyping method, and publications based on the same kind of analysis, (f) the analyst should provide a description 
of all aspects of the laboratory protocol used (e.g., PCR primer sequences) in response to a reasonable request, and $(\mathrm{g})$ a forensic insect species identification must include phylogenetic analysis of sequence data. They also asked (a) what research sample size is adequate for a species-diagnostic test to be used in court, (b) whether the DNA-Based species identification using BLAST search of the huge and easily queried GenBank /EMBL/DDBJ sequence database is critical enough, bearing in mind there are possible errors in some of these sequences, and (c) whether a taxonomic expert had confirmed the identification of the specimen the gene sequence of which was uploaded on the web.

These are important considerations as the analyst may need to testify in court about his findings, and above all, a forensic scientist must take great care to avoid a miscarriage of justice arising from careless interpretation of molecular data.

\section{Acknowledgements}

We thank Universiti Malaysia Sabah and Monash University Sunway for research facilities made available to us in the preparation of this paper.

\section{References}

[1] McKnight, B.E (1981). The washing away of wrongs: Forensic medicine in thirteenth-century China by Tz'u Sung. Translated by McKnight, B.E. University of Michigan, Ann Arbor,. 181 pp, ISSN 0892648007

[2] Gunn, A. (2006). Essential Forensic Biology. John Wiley \& Sons, Ltd, ISBN -10: 0470012773

[3] Sperling, F.A.H.; Anderson, G.S. \& Hickey, D.A. (1994). A DNA-based approach to the identification of insect species used for postmortem interval estimation. Journal Forensic Science, Vol. 39, No. , pp. 418-27. Erratum. 2000. Journal of Forensic Sciences, Vol. 45, pp. 1358-59, ISSN 1556-4029

[4] Benecke, M. (1998). Random amplified polymorphic DNA (RAPD) typing of necrophageous insects (Diptera, Coleoptera) in criminal forensic studies: validation and use in practice. Forensic Science International, Vol. 98, No. , pp. 157-168, ISSN 0379-07385. Wallman, J.F. \& Donnellan, S.C. (2001). The utility of mitochondrial DNA sequences for the identification of forensically important blowflies (Diptera: Calliphoridae) in southeastern Australia. Forensic Science International, Vol. 120, pp.60-67, ISSN 0379-0738

[5] Wallman, J.F. \& Donnellan, S.C. (2001). The utility of mitochondrial DNA sequences for the identification of forensically important blowflies (Diptera: Calliphoridae) in southeastern Australia. Forensic Science International, Vol. 120, pp.60-67, ISSN 03790738

[6] Wells, J.D. \& Sperling, F.A.H. (2001). DNA-based identification of forensically important Chrysomyinae (Diptera: Calliphoridae). Forensic Science International, Vol. 120, pp. 110-115, ISSN 0379-0738

[7] Wells, J.D.; Pape, T., \& Sperling, F.A. (2001). DNA-based identification and molecular systematic of forensically important Sarcophagidae (Diptera). Journal of Forensic Sciences, Vol. 46, pp. 1098-102, ISSN 1556-4029 
[8] Harvey, M.L.; Dadour, I.R. \& Gaudieri, S. (2003a). Mitochondrial DNA cytochrome oxidase I gene: potential for distinction between immature satges of some forensically important fly species (Diptera) in Western Australia. Forensic Science International, Vol. 131, pp. 134-139, ISSN 0379-073

[9] Harvey, M.L; Mansell, M.W.; Villet, M.H. \& Dadour, I.R. (2003b). Molecular identification of some forensically important blowflies of southern Africa and Australia. Medical and Veterinary Entomology, Vol. 17, pp. 363-369, ISSN 0269-283X

[10] Zehner, R.;Amendt J.; Schutt S.; Sauer J.; Krettek, R. \& Povolny, D. (2004). Genetic identification of forensically important flesh flies (Diptera: Sarcophagidae). International Journal of Legal Medicine, Vol. 118, pp. 245-247, ISSN 0937-9827

[11] Chen, W-Y.; Hung, T-H. \& Shiao, S.F. (2004). Molecular Identification of Forensically Important Blow Fly Species (Diptera: Calliphoridae) in Taiwan. Journal of Medical Entomology, Vol. 41, No. 1, pp. 47-57, ISSN 0022-2585

[12] Ames, C.; Turner, B. \& Daniel, B. (2006a). The use of mitochondrial cytochrome oxidase I gene (COI) to differentiate two UK blowfly species - Calliphora vicina and Calliphora vomitoria. Forensic Science International, Vol. 64, pp.179-182, ISSN 03790738

[13] Wells, J.D. \& Williams, D.W. (2007). Validation of a DNA-based method for identifying Chrysomyinae (Diptera: Calliphoridae) used in death investigation. International Journal of Legal Medicine, Vol. 121, pp.1-8, ISSN 0937-982718. Wells, J. D. \& Stevens, J. R. (2008). Application of DNA-Based Methods in Forensic Entomology. Annual Review of Entomology, Vol. 53, pp.103-20. ISSN 0066-4170

[14] Park, S.H.; Zhang, Y.; Piao, H.; Yu, D.H.; Jeong, H.J.; Yoo, G.Y.; Chung, U.; Jo, T-H. \& Hwang, J-J. (2009). Use of Cytochrome c Oxidase Subunit I (COI) Nucleotide Sequences for Identification of Korean Luciliinae Fly Species (Diptera: Calliphoridae) in Forensic Investigations. Journal of Korean Medical Science, Vol. 24, No. , pp. 1058-1063, ISSN 1011-8934

[15] Cai, J-F.; Liu, M.; Ying, B-W.; Deng, R-L.;Dong, J-G.; Zhang, L.; Tao, T.; Pan, H-F; Yang, H-T. \& Liao, Z-G. (2005). The availability of mitochondrial DNA cytochrome oxidase I gene for the distinction of forensically important flies in China. Acta Entomologica Sinica, Vol. 48, No. 3, pp. 380-385, ISSN 0454-6296

[16] Mazzanti, M.; Alessandrini, F.; Tagliabracci, A.; Wells, J.D. \& Campobasso, C.P. (2010). DNA Degradation and genetic analysis of empty puparia: Genetic identification limits in forensic entomology. Forensic Science International, Vol. 195, pp. 99-102, ISSN 0379-0738

[17] Dobler, S. \& Muller, J. K. (2000). Resolving phylogeny at the family level by mitochondrial cytochrome oxidase sequences: phylogeny of carrion beetles (Coleoptera: Silphidae). Molecular Phylogenetics and Evolution, Vol. 15, No. 3, pp. 390-402, ISSN

[18] Wells, J. D. \& Stevens, J. R. (2008). Application of DNA-Based Methods in Forensic Entomology. Annual Review of Entomology, Vol. 53, pp.103-20. ISSN 0066-4170

[19] Song, Z-K.; Wang, X-Z. \& Liang, G-Q. (2008). Species identification of some common necrophagous flies in Guangdong province, southern China based on the rDNA internal transcribed spacer 2 (ITS2). Forensic Science International, Vol. 175, pp. 17-22, ISSN 0379-0738 
[20] Wang, X.; Cai, J.; Guo, Y.; Chang, Y.; Wu, K.; Wang, J., Yang, L.; Lan, L.; Zhong, M.; Wang, X. ; Liu, Q.; Cheng, Y. S.; Liu, Y.; Chen, Y.; Li, J.; Zhang, J. \& Xin, P. (2010). The availability of 16SrDNA gene for identifying forensically important blowflies in China. Romanian Society of Legal Medicine, Vol.1, pp. 43 - 50, ISSN 1221-8618

[21] Zaidi, F., Wei, S-j., Shi, M. \& Chen, X-x. (2011). Utility of multi-geneloci for forensic species diagnosis of blowflies. Journal of Insect Sciences, Vol. 11, pp. 59, ISSN 15362442

[22] Nelson, L.A.; Wallman, J.F. \& Dowton, M. (2008). Identification of forensically important Chrysomya (Diptera: Calliphoridae) species using the second ribosomal internal transcribed spacer (ITS2). Forensic Science International, Vol. 177, No. , pp. 238-247, ISSN 0379-0738

[23] Schroeder, H., Klotzbach, H., Elias, S., Augustin C. \& Pueschel, K. (2003). Use of PCRRFLP for differentiation of calliphorid larvae (Diptera: Calliphoridae) on human corpses. Forensic Science International, Vol. 132, Pp.76-81, ISSN 0379-0738

[24] Chen, C-H. \& Shih, C-J. (2003). Rapid identification of three species of blowflies (Diptera: Calliphoridae) by PCR-RFLP and DNA sequencing analysis. Formosan Entomologist, Vol. 23, No. , pp. 59-70, ISSN 1680-7650

[25] Lin, H.; Wang, S.B.; Miao, X.X.; Wu, H. \& Huang, Y.P. (2007). Identification of necrophagous fly species using ISSR and SCAR markers. Forensic Science International, Vol. 168, No. 2-3, pp. 148-153,ISSN 0379-0738

[26] Jarrett, S.; Morgan, J.A.T.; Wlodek, B.M.; Brown, G.W.; Urech, R.; Green, P.E. \& LewTabor A.E. (2010). Specific detection of Old World screwworm fly, Chrysomya bezziana, in bulk fly trap catches using real-time PCR. Medical and Veterinary Entomology, Vol. 24, pp. 227-235, ISSN 0269-283X

[27] Donovan, S.E.; Hall, M.J.R.; Turner, B.D. \& Moncrieff, C.B. (2006). Larval growth rates of the blowfly, Calliphora vicina, over a range of temperatures. Medical and Veterinary Entomology, Vol. 20, No.1, pp. 106-114, ISSN 0269-283X

[28] Anderson, G.S. (2000). Minimum and maximum development rates of some forensically important Calliphoridae (Diptera). Journal of Forensic Sciences, Vol. 45, No. 2, pp. 842-832, ISSN 1556-4029

[29] Clark, K.; Evans, L. \& Wall, R. (2006). Growth rates of the blowfly, Lucillia sericata, on different body tissues. Forensic Science International, Vol. 156, No. 2-3, pp. 145-149, ISSN 0379-0738

[30] Gaudry, E.; Blais, C.; Maria, A. \& Dauphin-Villemant, C. (2006). Study of steriodogenesis in pupae of the forensically important blow fly Protophormia terraenovae (Robineau-Desvoidy) (Diptera: Calliphoridae). Forensic Science International, Vol. 160, No. 1, pp. 27-34, ISSN 0379-0738

[31] Tarone, A.M.; Jennings, K.C. \& Foran, D.R. (2007). Aging Blow Fly Eggs using Gene expression: A Feasibility Study. Journal of Forensic Sciences, Vol. 52, No.6, pp. 13501354, ISSN 1556-4029

[32] Tarone, A.M. \& Foran, D.R. (2011). Gene expression during blow fly development: improving the precision of age estimates in forensic entomology. Journal of Forensic Sciences, Vol. 56, pp. S114-S122, ISSN 1556-4029 
[33] Ames, C.; Turner, B. \& Daniel, B. (2006b). Estimating the post-mortem interval (II): The use of differential temporal gene expression to determine the age of blowfly pupae. International Congress Series 1288, pp. 861-863, ISSN 0531-5131

[34] Zehner, R.; Mösch, S. \& Amendt, J. (2006). Estimating the post-mortem interval by determining the age of fly pupae: Are there any molecular tools? International Congress Series, Vol. 1288, pp. 619-621, ISSN 0531-5131

[35] Hadrys, H., Balick, M. \& Schierwater, B. (1992). Applications of random amplified polymorphic DNA (RAPD) in molecular ecology. Molecular Ecology, Vol. 1, pp. 5563, ISSN 0962-1083

[36] Stevens, J. \& Wall, R. (1995). The use of random amplified polymorphic DNA (RAPD) analysis for studies of genetic variation in populations of the blowfly Lucilia sericata (Diptera: Calliphoridae) in southern England. Bulletin of Entomological Research, Vol. 85 , pp. 549-555, ISSN 0007-4853

[37] Picard, C.J. \& Wells, J.D. (2009). Survey of the genetic diversity of Phormia regina (Diptera: Calliphoridae) using amplified fragment length polymorphisms. Journal of Medical Entomology, Vol. 46, No. 3, pp. 664-670, ISSN 0022-2585

[38] Picard, C.J. \& Wells, J.D. (2010). The population genetic structure of North American Lucillia sericata (Diptera: Calliphoridae), and the utility of genetic assessment methods for reconstruction of post-mortem corpse relocation. Forensic Science International, Vol. 195, pp. 63-67, ISSN 0379-0738

[39] Kester, K.M.; Toothman, M.T.; Brown, B.L.; Street, W.S. \& Cruz, T.D. (2010). Recovery of environmental human DNA by insects. Journal of Forensic Sciences, Vol. 55, No. 6, pp. 1543-1551, ISSN 1556-4029

[40] Li, K.; Ye, G-Y.; Zhu, J-Y. \& Hu, C. (2007). Detection of food source by PCR analysis of the gut contents of Aldrinchina graham (Aldrich) (Diptera: Calliphoridae) during post-feeding period. Insect Science, Vol. 14, pp. 47-52, ISSN 1744-7917

[41] Spitaleri, S.; Romano, C.; Luise, E.D.; Ginestra, E. \& Saravo, L. (2006). Genptyping of human DNA recovered from mosquitoes found on a crime scene. International Congress Series, Vol. 1288, pp. 574-576, ISSN 0531-5131

[42] Szalanski, A.L.; Austin, J.W.; Mckern, J.A.; McCoy T.; Steelman, C.D. \& Miller, D.M. (2006). Time course analysis of bed bug, Cimex lectularius L., (Hemiptera: Cimicidae) blood meals with the use of polymerase chain reaction. Journal of Agricultural Urban Entomology, Vol. 23, No. 4, pp. 237-241, ISSN 1523-5475

[43] Mumcuoglu, K.Y.; Gallili, N.; Reshef, A.; Brauber, P. \& Grant, H. (2004). Use of Human Lice in Forensic Entomology. Journal of Medical Entomology, Vol. 41, No. 4, pp. 803806, ISSN 0022-2585

[44] Coulson, R.M.R.; Curtis, C.F.; Ready, P.D.; Hill, N. \& Smith, D.F. (1990). Amplification and analysis of human DNA present in mosquito blood meals. Medical and Veterinary Entomology, Vol. 4, No. , pp. 357-366, ISSN 0269-283X

[45] Zehner, R.; Amendt, J. \& Krettek, R. (2004). STR Typing of Human DNA from Fly Larvae Fed on Decomposing Bodies. Journal of Forensic Sciences, Vol. 49, No. 2, pp. 1-4, ISSN 1556-4029

[46] Kondakci, G.O.; Bulbul, O.; Shahzad, M.S.; Polat, E.; Cakan, H.; Altuncul, H. \& Filoglu, G. (2009). STR and SNP analysis of human DNA from Lucillia sericata larvae's gut contents. Forensic Science International, Genetic Supplement Series, Vol. 2, pp. 178-179, 1875-1768, ISSN 1875-1768 
[47] Lord, W.D.; DiZinno, J.A.; Wilson, M.R.; Budowle, B.; Taplin, D. \& Meinking, T.L. (1998). Isolation, amplification, and sequencing of human mitochondrial DNA obtained from human crab louse, Pthirus pubis (L.), blood meals. Journal of Forensic Sciences, Vol. 43, No. 2, pp. 1097-1100, ISSN 1556-4029 


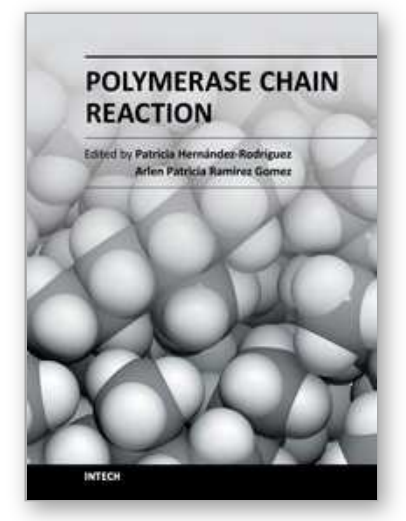

\author{
Polymerase Chain Reaction \\ Edited by Dr Patricia Hernandez-Rodriguez
}

ISBN 978-953-51-0612-8

Hard cover, 566 pages

Publisher InTech

Published online 30, May, 2012

Published in print edition May, 2012

This book is intended to present current concepts in molecular biology with the emphasis on the application to animal, plant and human pathology, in various aspects such as etiology, diagnosis, prognosis, treatment and prevention of diseases as well as the use of these methodologies in understanding the pathophysiology of various diseases that affect living beings.

\title{
How to reference
}

In order to correctly reference this scholarly work, feel free to copy and paste the following:

Tock Hing Chua and Y. V. Chong (2012). Role of Polymerase Chain Reaction in Forensic Entomology, Polymerase Chain Reaction, Dr Patricia Hernandez-Rodriguez (Ed.), ISBN: 978-953-51-0612-8, InTech, Available from: http://www.intechopen.com/books/polymerase-chain-reaction/role-of-polymerase-chainreaction-in-forensic-entomology

\section{INTECH}

open science | open minds

\author{
InTech Europe \\ University Campus STeP Ri \\ Slavka Krautzeka 83/A \\ 51000 Rijeka, Croatia \\ Phone: +385 (51) 770447 \\ Fax: +385 (51) 686166 \\ www.intechopen.com
}

\author{
InTech China \\ Unit 405, Office Block, Hotel Equatorial Shanghai \\ No.65, Yan An Road (West), Shanghai, 200040, China \\ 中国上海市延安西路65号上海国际贵都大饭店办公楼 405 单元 \\ Phone: +86-21-62489820 \\ Fax: +86-21-62489821
}


(C) 2012 The Author(s). Licensee IntechOpen. This is an open access article distributed under the terms of the Creative Commons Attribution 3.0 License, which permits unrestricted use, distribution, and reproduction in any medium, provided the original work is properly cited. 